\title{
Statistical comments on "no seasonal variation in physical activity of Han Chinese living in Beijing"
}

\author{
Mehrdad Farrokhi ${ }^{1^{*}}$ and Nasser Shirian ${ }^{2}$
}

\section{Dear Editor,}

We read with great interest the recent article by Wang et al. [1] entitled, "No seasonal variation in physical activity of Han Chinese living in Beijing". In this study, the authors evaluated physical activity levels every two months across a complete year, while simultaneously assessed ambient temperatures and air pollution levels. They also investigated average hourly vector magnitude and percentage time spent at each physical activity. In this regard, 40 Han Chinese adults using GT3X accelerometers were recruited. Although this study was mostly a well-designed research, we have the following comments from a statistical point of view. In the statistical analysis section of the article, the authors stated that they used one way ANOVA to compare whether there were changes in body weight and body fitness between months. One way ANOVA is used for comparison of the means of more than two independent groups [2-4]. But the groups of this study are not independent, because they did not use different groups at each time points of evaluation (every two months). Indeed, they measured their variables in one group of 40 adults every two months across a complete year. Therefore, there were not independent groups in this study and they investigated one group at different time points. After assessment of the normal distribution of studied quantitative variables, the authors must use Repeated Measures ANOVA or Friedman test for comparison of the means of each variable at different times of measurement.

Taken together, we believe that most used statistical tests in this study and also results and discussion based on them are inappropriate and the author's valuable study could better be used as citable clinical evidence if analyzed with appropriate statistical tests.

\footnotetext{
* Correspondence: mehrdadfarokhi72@yahoo.com

${ }^{1}$ Medical Student, School of Medicine, Isfahan University of Medical Sciences, Isfahan, Iran

Full list of author information is available at the end of the article
}

\section{Authors' contribution}

MF participated in the design of the study and mansucrtipt development. NS participated in the design of the study and manuscript development. Both authors read and approved the final manuscript.

\section{Competing interests \\ The authors declare that there is no conflict of interest regarding the publication of this article.}

\section{Publisher's Note}

Springer Nature remains neutral with regard to jurisdictional claims in published maps and institutional affiliations.

\section{Author details}

${ }^{1}$ Medical Student, School of Medicine, Isfahan University of Medical Sciences,

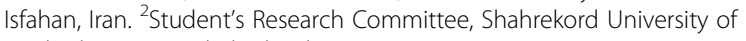
Medical Sciences, Shahrekord, Iran.

Received: 25 July 2017 Accepted: 20 October 2017

Published online: 03 November 2017

\section{References}

1. Wang $G$, et al. No seasonal variation in physical activity of Han Chinese living in Beijing. Int J Behav Nutr Phys Act. 2017;14(1):48.

2. Gaddis ML. Statistical methodology: IV. Analysis of variance, analysis of co variance, and multivariate analysis of variance. Acad Emerg Med. 1998;5(3):258-65.

3. Farrokhi M, Masoudifar A, Peykanpour F. Interleukin 17 and 10 in relapsing remitting multiple sclerosis. J Neurol Sci. 2017;378:63.

4. Farrokhi M. Sema3A and multiple sclerosis. Gene. 2017;615:41.
Submit your next manuscript to BioMed Central and we will help you at every step:

- We accept pre-submission inquiries

- Our selector tool helps you to find the most relevant journal

- We provide round the clock customer support

- Convenient online submission

- Thorough peer review

- Inclusion in PubMed and all major indexing services

- Maximum visibility for your research

Submit your manuscript at www.biomedcentral.com/submit
Biomed Central 